\title{
EPIDEMILOGY OF ENT DISORDERS IN ADULT POPULATION OF AGRICULTURAL REGION
}

DOI: 10.36740/WLek202105134

\author{
Vladyslav A. Smiianov, Tetiana V. Yemets, Yevhen V. Smiianov, Polina 0. Hornostaieva \\ SUMY STATE UNIVERSITY, SUMY, UKRAINE
}

\begin{abstract}
The aim: To study and analyze Sumy region population morbidity dynamics taking into account current stage of medical reform. Sumy region here is represented as one of the main agricultural regions of Ukraine. The prevalence of ENT disorders (otolaryngologic diseases) was studied.

Materials and methods: During the study we used data of statistical report of Public Health Board, Sumy State Administration for the period from 2015 to 2019 years by administrative territories. Obtained results were processed, using general statistics methods and analyzed, using structural-logical analysis.

Conclusions: The study found that the morbidity rates of ENT disorders in adult population during the study period increased and had levels of 2113.0 and 122.1 per 100 thousand adult population, respectively, and the prevalence rates and the prevalence rates of ENT disorders among the adult population decreased , respectively to 167.7; 2113,$0 ; 665.1$ and 389.9. All indicators have reliable differences in terms of administrative territories of the region.

The results of the study should be taken into account in the process of reforming the otolaryngological service in the region.
\end{abstract}

KEY WORDS: agricultural region, adult population, ENT disorders, morbidity, prevalence, index

\section{INTRODUCTION}

Ukraine now is in the middle of the process of reforming the country's health system [1] with the priority development of primary health care based on the principles of general medical practice - family medicine [2.3], the recognition of a general practitioner-family doctor as a doctor of first contact within the health system [4].

The second important direction of the reform is the introduction of a program of state guarantees of free medical care [5], accompanied by changes in the organization of activities and financing of health institutions [6].

At the same time, the need of the population in certain types of medical care that are determined by the morbidity and diseases prevalence levels in the population, is important in planning of the network and resources of health institutions.

In determining the relevance of the topic of the study, we assumed that ENT diseases are ones of the most common in the population $[7,8]$.

\section{THE AIM}

Investigate and analyze the dynamics of the morbidity in adult population of the Sumy region of Ukraine, as an agricultural region, and the prevalence of ENT diseases in them, taking into account the present stage of the health sector reform.

\section{MATERIALS AND METHODS}

During the study, data from the sectoral statistical reporting of the Health Department of the Sumy State
Administration for the period 2015-2019 in the context of administrative territories were used.

The results obtained during the study were processed using conventional statistical methods and analyzed using the structural logic analysis method.

This study was approved by the ethics committee of the Sumy State University, which determined that the general ethical rules of humane treatment of patients were observed when working with patients in accordance with the requirements of the Tokyo Declaration of the World Medical Association and the International Recommendations of the Helsinki Declaration of Human Rights.

\section{REVIEW AND DISCUSSION}

At the first stage of the study, an analysis of the morbidity rates in adult population of the Sumy region with ENT diseases was carried out.

Table 1 demonstrates data on the morbidity rates in adult population of the region with ear diseases by the administrative territories of the region in the dynamics of 2015-2019 (Table 1).

An analysis of the data presented in Table 1 indicates that in the whole area, the morbidity rate in adult population with ear disease increased by $47.1 \%$ and equals 2113.0 per 100 adults. At the same time, increasing of this index was recorded in the territory of $17(94.4 \%)$ rural administrative territories and 4 (57.1\%) cities (towns) of the region. The largest level of index increasing was recorded in the territory of the Seredyna-Buda distcrict (347.6\%) which equals 496.7 per 100 adults. 
Table 1. Sumy region ear diseases morbidity rate in adult population, 2015-2019yrs. (per 100 thousand of adult population)

\begin{tabular}{|c|c|c|c|c|c|c|}
\hline \multirow{2}{*}{ Administrative territory } & \multicolumn{5}{|c|}{ years/rates (indexes) } & \multirow{2}{*}{$\begin{array}{c}2019 \text { to } 2015 \text { yrs. } \\
\%\end{array}$} \\
\hline & 2015 & 2016 & 2017 & 2018 & 2019 & \\
\hline Sumy region & 1436,4 & 1489,2 & 1509,2 & 1363,8 & 2113,0 & 147,1 \\
\hline \multicolumn{7}{|l|}{ Districts of the region } \\
\hline Bilopillia & 1645,4 & 1681,1 & 1682,0 & 1621,8 & 2488,1 & 151,2 \\
\hline Buryn & 1617,1 & 1665,8 & 1555,8 & 1541,8 & 3331,7 & 206,0 \\
\hline Velyka Pysarivka & 775,9 & 654,8 & 988,0 & 1524,2 & 2103,0 & 271,0 \\
\hline Hlukhiv & 1233,7 & 1002,3 & 862,7 & 862,1 & 1365,8 & 110,7 \\
\hline Konotop & 1248,3 & 1270,3 & 1405,7 & 1274,4 & 1736,5 & 139,1 \\
\hline Krasnopillia & 593,3 & 1075,0 & 795,7 & 783,4 & 1540,9 & 259,7 \\
\hline Krolevets & 2279,7 & 2359,5 & 2253,9 & 1984,1 & 3407,2 & 149,5 \\
\hline Lebedyn & 1264,5 & 1812,1 & 1218,7 & 1485,8 & 2320,6 & 183,5 \\
\hline Lypova Dolyna & 1219,4 & 1429,9 & 1256,8 & 1121,8 & 2257,8 & 185,2 \\
\hline Nedryhailiv & 706,0 & - & 28,8 & 203,7 & 635,6 & 90,0 \\
\hline Okhtyrka & 1312,8 & 1503,2 & 1509,2 & 1488,2 & 1961,4 & 149,4 \\
\hline Putyvl' & 1007,0 & 823,9 & 1127,8 & 1360,9 & 1968,1 & 195,4 \\
\hline Romny & 1657,5 & 1899,2 & 2251,4 & 2633,8 & 3577,0 & 215,8 \\
\hline Seredyna-Buda & 142,9 & 333,6 & 1063,8 & 1680,6 & 496,7 & 347,6 \\
\hline Sumy & 1399,5 & 1421,4 & 1420,6 & 1421,7 & 2492,2 & 178,1 \\
\hline Trostianets & 1132,6 & 1644,7 & 1546,4 & 1894,1 & 2814,5 & 248,5 \\
\hline Shostka & 1371,6 & 1268,3 & 1520,9 & 1463,8 & 2230,4 & 162,6 \\
\hline Yampil & 572,5 & 743,9 & - & - & 1541,2 & 269,2 \\
\hline \multicolumn{7}{|l|}{ Towns of the region } \\
\hline Sumy (city) & 1889,5 & 1879,7 & 1804,9 & 997,4 & 1807,5 & 95,7 \\
\hline Hlukhiv (town) & 1585,0 & 1303,7 & 1129,4 & 1244,5 & 1390,1 & 101,0 \\
\hline Konotop (town) & 1376,8 & 1422,4 & 1629,2 & 1449,1 & 1375,9 & 99,9 \\
\hline Lebedyn (town) & 1773,2 & 2178,0 & 1585,5 & 1823,1 & 1430,1 & 80,6 \\
\hline Okhtyrka (town) & 1684,8 & 1794,3 & 1787,7 & 1841,9 & 1849,4 & 109,8 \\
\hline Romny (town) & 2252,1 & 2220,7 & 2649,1 & 3275,5 & 3761,3 & 167,0 \\
\hline Shostka (town) & 1540,0 & 1438,9 & 1748,3 & 2492,6 & 2178,5 & 141,5 \\
\hline
\end{tabular}

The margin difference of the index by administrative districts of the region equals 7.2 times: from 496.7 in Seredyna-Buda dt. to 3577.0 in Romny dt. At the same time, in 2016 in Nedryhailiv dt. and in 2017- 2018 in the Yampil $\mathrm{dt}$, according to official statistical reports, ear diseases in adult population were not recorded at all.

The margin index difference by cities of the region is 2.7 times: from 1375.9 in Konotop to 3761.3 in Romny.

In the structure of level indexes of ear diseases, the main diseases in 2019 were middle ear and papilliform process diseases (32.7\% with an indicator of 691.5), hearing loop (2.5\% with an indicator of 52.0$)$, chronic otitis of the middle ear $(0.6 \%$ with an indicator of 11.9$)$.

Further, the analysis of the morbidity rates of the adult population of the Sumy region by administrative territories for the period 2015-2019 throat disease was conducted. The obtained data are given in Table 2.
Analysis of the data given in Table 2 indicates that during the study period, the current morbidity rate in adult population of the region decreased by $17.9 \%$ and equaled to 167.7 per 100 thousand adult population.

By the rural administrative territories of the region, this index differs 42.1 times: from 13.5 in Lebedyn to 568.5 in Romny dt. At the same time, in the territory of 10 (55.6\%) districts during the study, the increasing of morbidity with throat diseases in adults was recorded, and in the territory of $7(38.9 \%)$ districts, on the contrary, the decreasing was recorded. The highest rate of increasing in the morbidity rate was recorded in Krasnopillia dt (335.5\%), and the highest rate of decreasing was recorded in Lebedyn $(77.3 \%) \mathrm{dt}$. Among cities (towns) of the region, the margin difference the index varies in 15.6 times: from 18.0 in Lebedyn to 281.2 in Romny. At the same time, in the territory of 3 (42.9\%) towns during the study period, an increasing of 
Table 2. Sumy region throat diseases morbidity rate in adult population, 2015-2019 yrs. (per 100 thousand of adult population)

\begin{tabular}{|c|c|c|c|c|c|c|}
\hline \multirow{2}{*}{ Administrative territory } & \multicolumn{5}{|c|}{ years/rates (indexes) } & \multirow{2}{*}{$\begin{array}{c}2019 \text { to } 2015 \text { yrs. } \\
\%\end{array}$} \\
\hline & 2015 & 2016 & 2017 & 2018 & 2019 & \\
\hline Sumy region & 204,3 & 215,8 & 212,2 & 189,5 & 167,7 & 82,1 \\
\hline \multicolumn{7}{|l|}{ Region districts } \\
\hline Bilopillia & 313,9 & 318,6 & 321,0 & 283,5 & 238,6 & 76,0 \\
\hline Buryn & 79,4 & 93,5 & 208,4 & 197,6 & 154,3 & 194,3 \\
\hline Velyka Pysarivka & 17,9 & - & 16,0 & 40,3 & 50,2 & 280,4 \\
\hline Hlukhiv & 270,7 & 246,1 & 192,9 & 196,4 & 209,1 & 77,4 \\
\hline Konotop & 217,1 & 206,3 & 221,4 & 196,2 & 195,9 & 90,2 \\
\hline Krasnopillia & 39,2 & 81,3 & 86,5 & 61,5 & 131,5 & 335,5 \\
\hline Krolevets & 202,0 & 193,7 & 174,6 & 203,1 & 213,3 & 105,6 \\
\hline Lebedyn & 59,5 & 182,0 & 7,9 & 32,4 & 13,5 & 22,7 \\
\hline Lypova Dolyna & 81,3 & 53,7 & 116,2 & 104,5 & 96,7 & 118,9 \\
\hline Nedryhailiv & 69,3 & - & 14,4 & - & 46,3 & 66,8 \\
\hline Okhtyrka & 118,0 & 147,9 & 157,0 & 155,5 & 126,1 & 106,9 \\
\hline Putyvl' & 288,3 & 176,7 & 208,4 & 171,3 & 484,7 & 168,1 \\
\hline Romny & 306,4 & 418,9 & 549,9 & 607,8 & 568,5 & 185,5 \\
\hline Seredyna-Buda & - & 31,9 & 168,7 & 117,5 & 51,2 & - \\
\hline Sumy & 233,6 & 185,9 & 195,7 & 199,1 & 179,5 & 76,8 \\
\hline Trostianets & 74,2 & 101,3 & 94,9 & 100,8 & 90,9 & 122,5 \\
\hline Shostka & 223,5 & 177,6 & 240,9 & 133,9 & 99,9 & 44,7 \\
\hline Yampil & 255,2 & 241,4 & 238,9 & 304,6 & 279,8 & 109,6 \\
\hline \multicolumn{7}{|l|}{ Towns of the region } \\
\hline Sumy (city) & 264,4 & 289,7 & 216,8 & 161,7 & 88,8 & 33,6 \\
\hline Hlukhiv (town) & 341,9 & 312,3 & 211,4 & 224,1 & 287,1 & 118,7 \\
\hline Konotop (town) & 230,2 & 239,1 & 250,9 & 116,5 & 237,0 & 103,0 \\
\hline Lebedyn (town) & 106,9 & 195,7 & 9,4 & 31,2 & 19,2 & 18,0 \\
\hline Okhtyrka (town) & 157,1 & 174,2 & 209,1 & 232,2 & 128,3 & 81,7 \\
\hline Romny (town) & 370,7 & 562,2 & 714,8 & 811,5 & 1042,4 & 281,2 \\
\hline Shostka (town) & 247,2 & 207,7 & 261,8 & 199,4 & 120,1 & 48,6 \\
\hline
\end{tabular}

the index was recorded, and in the territory of $4(57.1 \%)$ towns decreasing was registered.

In the structure of the morbidity rates in adult population the next throat diseases are leading: chronic glands and adenoid diseases $-45.6 \%$ with an index of 76.4 ; chronic pharyngitis $-43.9 \%$ with an index of 73.6 ; chronic laryngitis, laryngotracheitis $-10.6 \%$ with an index of 17.7 per 100 thousand adult population.

The next step of the study was to investigate and to analyze the morbidity rates in adult population of the Sumy region with nasal diseases in the dynamics of 2015-2019 yrs. by administrative territories of the region. The results obtained are presented in Table 3.

The analysis of the data given in Table 3 indicates that during the study period, the morbidity rate in adult population of the region during the study period decreased by $3.5 \%$ and equaled 122.1 per 100 thousand adult population. The margin difference of the index by administrative rural areas varies by 144.7 times: from 2.7 in Lebedyn dt. to 390.7 in the Romny $\mathrm{dt}$., and mong town the index varies by 6.4 times: from 85.9 in Sumy to 553.4 in Romny, in the absence of data on recorded cases in adults of nasal diseases was registred in Lebedyn.

During the study period, the largest decreasing in the imorbidity with nasal diseases in adults was recorded (25.4 times) in Lebedyn dt.; increasing was registered in Seredyna-Buda (7.7 times) district.

In the structure of disease prevalence level, the main lines are presented with vasomotor and allergic rhinitis $(51.4 \%$ with an index of 62.7); chronic rhinitis, nasopharyngitis (40.1\% with an index 49.0$)$; chronic sinusitis (8.5\% with an index of 10.4).

The second phase of the study investigated and analyzed prevalence rates of ear, throat and nose diseases (ENT) in adult population of Sumy region. 
Table 3. Sumy region nasal diseases morbidity rate in adult population, 2015-2019 yrs. (per 100 thousand of adult population)

\begin{tabular}{|c|c|c|c|c|c|c|}
\hline \multirow{2}{*}{ Administrative territory } & \multicolumn{5}{|c|}{ years/rates (indexes) } & \multirow{2}{*}{$\begin{array}{c}2019 \text { to } 2015 \text { yrs. } \\
\%\end{array}$} \\
\hline & 2015 & 2016 & 2017 & 2018 & 2019 & \\
\hline Sumy region & 118,0 & 128,1 & 138,1 & 132,6 & 122,1 & 103,5 \\
\hline \multicolumn{7}{|l|}{ Region districts } \\
\hline Bilopillia & 146,3 & 151,8 & 150,1 & 139,9 & 98,3 & 67,2 \\
\hline Buryn & 40,6 & 43,0 & 137,0 & 130,2 & 51,0 & 125,6 \\
\hline Velyka Pysarivka & 17,9 & 18,2 & 21,1 & 41,6 & 33,4 & 186,6 \\
\hline Hlukhiv & 144,7 & 132,7 & 109,5 & 81,8 & 135,1 & 93,6 \\
\hline Konotop & 89,2 & 105,4 & 141,4 & 131,6 & 108,0 & 121,1 \\
\hline Krasnopillia & 36,0 & 59,7 & 66,8 & 55,3 & 50,7 & 140,8 \\
\hline Krolevets & 20,1 & 37,3 & 66,9 & 109,4 & 106,4 & $+5,3 \mathrm{p}$ \\
\hline Lebedyn & 68,5 & 135,2 & 15,7 & 4,8 & 2,7 & 0,4 \\
\hline Lypova Dolyna & 50,7 & 83,7 & 130,1 & 80,0 & 110,4 & 219,0 \\
\hline Nedryhailiv & 33,7 & 23,6 & 34,4 & 14,6 & 27,3 & 81,0 \\
\hline Okhtyrka & 150,3 & 180,3 & 180,8 & 192,8 & 190,6 & 126,8 \\
\hline Putyvl' & 175,5 & 123,4 & 108,9 & 141,0 & 181,2 & 103,2 \\
\hline Romny & 216,6 & 279,8 & 341,7 & 420,3 & 390,7 & 180,4 \\
\hline Seredyna-Buda & 21,4 & 33,4 & 80,8 & 195,0 & 165,3 & $+7,7 \mathrm{p}$ \\
\hline Sumy & 102,7 & 101,0 & 114,0 & 120,4 & 120,4 & 117,2 \\
\hline Trostianets & 88,1 & 67,5 & 99,6 & 78,7 & 42,0 & 47,7 \\
\hline Shostka & 159,9 & 121,3 & 171,8 & 84,4 & 130,5 & 81,6 \\
\hline Yampil & 152,4 & 103,5 & 144,3 & 154,4 & 156,3 & 102,6 \\
\hline \multicolumn{7}{|l|}{ Towns of the region } \\
\hline Sumy (city) & 172,6 & 162,0 & 146,0 & 133,6 & 85,9 & 49,8 \\
\hline Hlukhiv (town) & 184,1 & 169,0 & 109,7 & 81,6 & 159,7 & 86,7 \\
\hline Konotop (town) & 105,0 & 120,7 & 149,0 & 141,4 & 125,3 & 119,3 \\
\hline Lebedyn (town) & 100,4 & 160,6 & 18,7 & 1,9 & - & - \\
\hline Okhtyrka (town) & 214,7 & 251,3 & 254,0 & 273,1 & 274,4 & 127,8 \\
\hline Romny (town) & 290,5 & 374,9 & 392,0 & 536,0 & 553,4 & 257,8 \\
\hline Shostka (town) & 177,2 & 136,0 & 190,6 & 139,7 & 159,0 & 89,7 \\
\hline
\end{tabular}

The results of the study of prevalence rates in adult population of the Sumy region by administrative territories for the period 2015-2019 of ear diseases are given in Table 4.

Analysis of the data given in Table 4 indicates that during the study period, the prevalence rate of ear diseases in adult population of the Sumy region decreased by $13.6 \%$ and equaled 2113.0 per 100 thousand. At the same time, in the territory of $13(72.2 \%)$ administrative rural disctricts and 4 (57.1\%) towns there was an increasing in this index. Among administrative rural areas, the prevalence rates of ear diseases in adult population varies in 7.2 times: from 496.7 in Seredyna-Buda to 3577.0 in Romny district. Among towns, a 2.5-fold variation of this index was recorded: from 1807.5 in Sumy to 4557.7 in Romny.

In the structure of the prevalence rate of ear diseases in adult population of the Sumy region, the following diseases occur the most: middle ear and papillifom process diseases
(32.7\% with an indicator of 691.5); hearing loop (8.3\% with an index of 176.2), chronic otitis of the middle ear $(7.8 \%$ with an index of 164.9).

Further, the issue of prevalence rates of throat diseases in adult population of the Sumy region was studied and analyzed. The results of the study of these prevalence rates (throat diseases) by administrative territories for the period 2015-2019 are given in Table 5.

The analysis of the data given in Table 5 indicates that in the region during the study period, the prevalence rate of throat diseases in adult population decreased by $13.3 \%$ and amounted to 665.1 per 100 thousand people. By administrative territories of the region, this indicator has reliable differences. Thus, by administrative rural areas, the margin difference of the index varies in 3.8 times: from 310.0 in Velyka Pysarivka dt. to 1188.2 in Putyvl district and 2.5 times among the towns of the region: from 553.5 Okhtyrka to 1375.2 in Romny. 
Table 4. Sumy region ear diseases prevalence rate in adult population, 2015-2019 yrs. (per 100 thousand of adult population)

\begin{tabular}{|c|c|c|c|c|c|c|}
\hline \multirow{2}{*}{ Administrative territory } & \multicolumn{5}{|c|}{ years/rates } & \multirow{2}{*}{$\begin{array}{c}2019 \text { to } 2015 \text { yrs. } \\
\%\end{array}$} \\
\hline & 2015 & 2016 & 2017 & 2018 & 2019 & \\
\hline Sumy region & 2445,8 & 2577,8 & 2554,7 & 2289,7 & 2113,0 & 86,4 \\
\hline \multicolumn{7}{|l|}{ Region districts } \\
\hline Bilopillia & 2623,4 & 2687,0 & 2682,8 & 2563,5 & 2488,1 & 94,8 \\
\hline Buryn & 3090,9 & 3534,5 & 3226,9 & 3103,1 & 3331,7 & 107,8 \\
\hline Velyka Pysarivka & 889,3 & 782,1 & 1253,5 & 2072,2 & 2103,0 & 236,5 \\
\hline Hlukhiv & 1835,0 & 1529,6 & 1310,9 & 1324,3 & 1365,8 & 74,4 \\
\hline Konotop & 1921,3 & 2152,5 & 2048,1 & 1854,4 & 1736,5 & 90,4 \\
\hline Krasnopillia & 1224,2 & 3897,8 & 1381,8 & 1428,4 & 1540,9 & 125,9 \\
\hline Krolevets & 3950,8 & 3986,6 & 3842,2 & 3430,8 & 3407,2 & 86,2 \\
\hline Lebedyn & 2136,5 & 2945,6 & 2398,1 & 2843,9 & 2320,6 & 108,6 \\
\hline Lypova Dolyna & 2143,3 & 2322,8 & 2185,2 & 2058,8 & 2577,8 & 120,3 \\
\hline Nedryhailiv & 2161,9 & 377,8 & 426,9 & 572,4 & 635,6 & 29,4 \\
\hline Okhtyrka & 1894,4 & 2105,2 & 2183,3 & 2285,0 & 1961,4 & 103,5 \\
\hline Putyvl' & 1583,7 & 1085,9 & 1595,3 & 1813,0 & 1968,1 & 124,3 \\
\hline Romny & 2347,9 & 2501,2 & 2858,6 & 3412,4 & 3577,0 & 152,3 \\
\hline Seredyna-Buda & 364,4 & 558,4 & 1342,5 & 2000,3 & 496,7 & 136,3 \\
\hline Sumy & 2338,9 & 2352,9 & 2531,7 & 2510,3 & 2492,2 & 106,6 \\
\hline Trostianets & 2046,7 & 2445,1 & 2587,6 & 2729,0 & 2814,5 & 137,5 \\
\hline Shostka & 1821,4 & 1752,4 & 2227,5 & 2123,5 & 2230,4 & 122,5 \\
\hline Yampil & 834,5 & 965,6 & 1293,9 & 1608,6 & 1541,2 & 184,7 \\
\hline \multicolumn{7}{|l|}{ Towns of the region } \\
\hline Sumy (city) & 3708,8 & 3755,0 & 3686,5 & 2369,8 & 1807,5 & 48,7 \\
\hline Hlukhiv (town) & 2260,2 & 1909,0 & 1634,5 & 1841,3 & 1908,4 & 84,4 \\
\hline Konotop (town) & 2078,1 & 2187,8 & 2172,3 & 2060,0 & 1968,9 & 94,7 \\
\hline Lebedyn (town) & 2390,4 & 2410,1 & 2782,8 & 3835,7 & 2972,2 & 124,3 \\
\hline Okhtyrka (town) & 2224,2 & 2738,4 & 2534,6 & 2760,4 & 2356,4 & 105,9 \\
\hline Romny (town) & 2963,4 & 2787,2 & 3160,2 & 3204,9 & 4557,7 & 153,8 \\
\hline Shostka (town) & 2017,6 & 1958,8 & 2483,4 & 3554,7 & 2750,0 & 136,3 \\
\hline
\end{tabular}

During the study period, by administrative territories of the region, the index fluctuated both downward and upward. The largest level of decreasing was registered in Hlukhiv (34.3\%), and the largest level of increasing was registered in Lebedyn (222.5\%).

In the structure of the prevalence of throat diseases in adult population, the most typical are chronic glands and adenoid diseases $(48.4 \%$ with an indicator of 322.1$)$, chronic pharyngitis (34.9\% with an indicator of 232.7$)$, chronic laryngitis, laryngotracheitis (16.6\% with an indicator of 110.4 ).

The next step of the study was to examine prevalence rates of nasal diseases in adults. The results of the study of prevalence rates of nasal diseases in adult population of the Sumy region by administrative territories for the period 2015-2019 are given in Table 6.

An analysis of the data in Table 6 indicates that the prevalence of nasal diseases in the adult population tends to decrease in the area during the study period. The decreasing rate was $1.7 \%$ with an indicator of 389.9 per 100 thousand adult population of the region. Among administrative territories of the region, the margin difference of the indicator varies 3.4 times: from 190.9 in Konotop to 644.7 in Putyvl district. Among towns, this indicator ranges from 337.6 in Konotop to 766.5 in Romny, which is 2.3 times. At the same time, the indicator increased in 16 (64.0\%) of the administrative territories of the region, and in 9 (36.0\%) of the administrative territories one registered a decreasing process.

In the structure of the prevalence rate of nasal diseases in adult population, vasomotor and allergic rhinitis $(44.3 \%$ with an index of 172.9), chronic rhinitis, nasopharyngitis (39.8\% with an index of 155.2), chronic sinusitis (15.9\% with an index of 61.8) occupy the main lines.

The study obtained data on the morbidity rates in adult population of Sumy region with diseases of ear, throat 
Table 5. Sumy region throat diseases prevalence rate in adult population, 2015-2019 yrs. (per 100 thousand of adult population)

\begin{tabular}{|c|c|c|c|c|c|c|}
\hline \multirow{2}{*}{ Administrative territory } & \multicolumn{5}{|c|}{ years/rates } & \multirow{2}{*}{$\begin{array}{c}2019 \text { to } 2015 \text { yrs. } \\
\%\end{array}$} \\
\hline & 2015 & 2016 & 2017 & 2018 & 2019 & \\
\hline Sumy region & 767,2 & 761,6 & 735,3 & 773,2 & 665,1 & 86,7 \\
\hline \multicolumn{7}{|l|}{ Region districts } \\
\hline Bilopillia & 528,9 & 539,3 & 545,5 & 494,1 & 472,6 & 89,4 \\
\hline Buryn & 910,2 & 928,7 & 969,1 & 834,6 & 1038,1 & 114,1 \\
\hline Velyka Pysarivka & 174,7 & 161,3 & 227,2 & 317,4 & 310,0 & 177,4 \\
\hline Hlukhiv & 779,1 & 648,2 & 647,0 & 617,0 & 555,9 & 71,4 \\
\hline Konotop & 987,5 & 900,1 & 855,3 & 744,2 & 795,5 & 80,6 \\
\hline Krasnopillia & 311,6 & 370,9 & 383,3 & 429,4 & 437,7 & 140,5 \\
\hline Krolevets & 904,7 & 906,3 & 868,2 & 839,3 & 814,9 & 90,1 \\
\hline Lebedyn & 402,7 & 595,9 & 534,8 & 606,5 & 524,5 & 130,2 \\
\hline Lypova Dolyna & 386,8 & 359,7 & 420,6 & 424,5 & 420,6 & 108,7 \\
\hline Nedryhailiv & 910,7 & 657,4 & 670,6 & 794,6 & 853,4 & 93,7 \\
\hline Okhtyrka & 558,2 & 600,6 & 596,3 & 516,3 & 512,1 & 91,7 \\
\hline Putyvl' & 567,9 & 487,6 & 530,0 & 621,7 & 1188,2 & 209,2 \\
\hline Romny & 1005,3 & 970,3 & 1099,0 & 1019,4 & 983,4 & 97,8 \\
\hline Seredyna-Buda & 458,7 & 496,1 & 688,2 & 603,8 & 718,0 & 156,5 \\
\hline Sumy & 735,8 & 747,3 & 754,4 & 738,4 & 765,3 & 104,0 \\
\hline Trostianets & 665,0 & 794,3 & 753,0 & 880,5 & 700,5 & 105,3 \\
\hline Shostka & 618,1 & 653,6 & 804,5 & 875,7 & 623,6 & 100,9 \\
\hline Yampil & 612,3 & 678,0 & 448,9 & 637,4 & 455,2 & 74,3 \\
\hline \multicolumn{7}{|l|}{ Towns of the region } \\
\hline Sumy (city) & 977,6 & 959,9 & 786,5 & 977,8 & 661,1 & 67,6 \\
\hline Hlukhiv (town) & 968,8 & 776,5 & 713,6 & 652,8 & 636,6 & 65,7 \\
\hline Konotop (town) & 923,9 & 867,7 & 903,2 & 779,8 & 754,2 & 81,6 \\
\hline Lebedyn (town) & 427,4 & 612,9 & 604,2 & 745,3 & 951,1 & 222,5 \\
\hline Okhtyrka (town) & 665,1 & 660,3 & 696,6 & 608,2 & 553,5 & 83,2 \\
\hline Romny (town) & 1350,0 & 1250,5 & 1350,7 & 1241,8 & 1375,2 & 101,9 \\
\hline Shostka (town) & 689,8 & 923,5 & 902,2 & 1478,8 & 728,0 & 105,5 \\
\hline
\end{tabular}

and nose (ENT) and main diseases in their structure and prevalence rates of these diseases in adult population of the region. These indicators were analyzed in the dynamics of 2015 -2019 years and by comparing the statistics of the administrative territories of the region. The data obtained indicate that in the dynamics of the study years, an increasing in the morbidity rates of ear diseases in adult population is recorded; the morbidity rates of nasal diseases also tend to increase. The remaining indicators, including the morbidity with throat diseases and the prevalence of ear, throat and nose diseases, are showing tendence to decrease.

Significant fluctuations in all the studied indexes among administrative territories of the region deserve high attention. According to some indicators, some differences vary for more than a hundred times. This situation is indicated by the authors who studied the morbidity rates and the prevalence of various diseases in adult population in other regions of Ukraine $[9,10]$. The reason for current situation, which requires a special in-depth study, may be caused by different level of accessibility of the population from different administrative territories to certain types of specialized medical care and shortcomings in the organization of statistical records of the state of health of the population.

\section{CONCLUSIONS}

In the course of the study, the dynamics of indicators and levels of morbidity of ear, throat and nose diseases (ENT) in adult population of the Sumy region, as an agricultural region of the country, the dynamics and levels of this category diseases prevalence in adult population of the region were stated. The data of the analysis should be taken into account in the process of reforming the otolaryngological service in the region. 
Table 6. Sumy region nasal diseases prevalence rate in adult population, 2015-2019 yrs. (per 100 thousand of adult population)

\begin{tabular}{|c|c|c|c|c|c|c|}
\hline \multirow{2}{*}{ Administrative territory } & \multicolumn{5}{|c|}{ years/rates } & \multirow{2}{*}{$\begin{array}{c}2019 \text { to } 2015 \text { yrs. } \\
\%\end{array}$} \\
\hline & 2015 & 2016 & 2017 & 2018 & 2019 & \\
\hline Sumy region & 396,6 & 392,6 & 393,9 & 408,4 & 389,9 & 98,3 \\
\hline \multicolumn{7}{|l|}{ Region districts } \\
\hline Bilopillia & 384,8 & 401,4 & 400,6 & 359,5 & 289,9 & 75,3 \\
\hline Buryn & 420,4 & 458,7 & 338,6 & 430,3 & 429,9 & 102,2 \\
\hline Velyka Pysarivka & 76,4 & 99,5 & 143,3 & 203,4 & 217,4 & 284,6 \\
\hline Hlukhiv & 370,0 & 339,4 & 338,3 & 247,2 & 349,0 & 94,3 \\
\hline Konotop & 323,3 & 338,2 & 358,4 & 337,6 & 190,9 & 59,1 \\
\hline Krasnopillia & 198,6 & 233,4 & 316,7 & 272,2 & 280,8 & 141,4 \\
\hline Krolevets & 360,9 & 372,3 & 392,0 & 385,5 & 338,4 & 93,8 \\
\hline Lebedyn & 284,7 & 412,1 & 353,1 & 438,0 & 391,9 & 137,6 \\
\hline Lypova Dolyna & 253,8 & 308,4 & 343,6 & 283,0 & 327,8 & 129,2 \\
\hline Nedryhailiv & 365,1 & 300,5 & 330,1 & 332,8 & 378,1 & 103,6 \\
\hline Okhtyrka & 382,1 & 437,9 & 415,8 & 411,7 & 389,4 & 101,9 \\
\hline Putyvl' & 413,6 & 423,4 & 399,2 & 452,7 & 644,7 & 155,9 \\
\hline Romny & 543,5 & 496,0 & 522,2 & 604,8 & 580,8 & 106,9 \\
\hline Seredyna-Buda & 177,2 & 214,6 & 287,6 & 325,7 & 328,2 & 185,2 \\
\hline Sumy & 230,6 & 385,3 & 383,2 & 382,6 & 397,1 & 172,2 \\
\hline Trostianets & 255,5 & 252,6 & 271,1 & 278,8 & 216,1 & 93,7 \\
\hline Shostka & 420,6 & 402,8 & 516,8 & 516,8 & 493,2 & 117,3 \\
\hline Yampil & 320,0 & 301,0 & 293,3 & 303,2 & 346,2 & 108,2 \\
\hline \multicolumn{7}{|l|}{ Towns of the region } \\
\hline Sumy (city) & 494,2 & 460,5 & 376,8 & 433,6 & 379,4 & 76,8 \\
\hline Hlukhiv (town) & 477,2 & 419,8 & 404,8 & 231,5 & 432,9 & 90,7 \\
\hline Konotop (town) & 344,4 & 349,3 & 383,6 & 352,2 & 337,6 & 98,0 \\
\hline Lebedyn (town) & 346,3 & 459,8 & 424,6 & 618,4 & 544,6 & 157,3 \\
\hline Okhtyrka (town) & 475,5 & 530,1 & 510,9 & 477,9 & 453,6 & 95,4 \\
\hline Romny (town) & 730,8 & 601,5 & 674,3 & 704,7 & 766,5 & 104,9 \\
\hline Shostka (town) & 464,3 & 333,6 & 542,3 & 829,2 & 519,4 & 118,9 \\
\hline
\end{tabular}

\section{REFERENCES}

1. Natsional'na stratehiya reformuvannya systemy okhorony zdorov'ya $v$ Ukrayini na period 2015-2020 rokiv. [National strategy of health care reform in Ukraine for the period 2015-2020]. Strategic Advisory Group on Health Care Reform in Ukraine. 2015; 41. http://healthsag.org.ua/ strategiya/. (in Ukrainian).

2. Musii 0.S. Shchorichna dopovid pro stan zdorovia naselennia, sanitarno-epidemichnu sytuatsiiu ta rezultaty diialnosti systemy okhorony zdorovia Ukrainy. 2013 rik [Annual report on the state of health of the population, the sanitary-epidemic situation and the results of activity of the health care system of Ukraine. 2013]. Kyiv. 2014. (in Ukrainian).

3. Slabkyy H.0., Zozulya I.S., Zozulya A.I. Priorytetnyy rozvytok pervynnoyi medyko-sanitarnoyi dopomohy na zasadakh simeynoyi medytsyny. [Priority development of primary health care on the basis of family medicine]. Family Medicine. 2014; 3 (53): 25-27. (in Ukrainian).
4. Nakaz M0ZUkrainy vid 19.03.2018 №504 «Pro zatverdzhennia Poriadku nadannia pervynnoi medychnoi dopomohy». [Order of the Ministry of Health of Ukraine from 19.03.2018 №504 «0n approval of the Procedure for the provision of primary medical care»]. https://moz.gov.ua/article/ ministry-mandates/nakaz-moz-ukraini-vid-19032018--504-prozatverdzhennja-porjadku-nadannja-pervinnoi-medichnoi-dopomogi. (in Ukrainian).

5. ZakonUkrainy «Proderzhavni nansoviharantiimedychnoho obsluhovuvannia naselennia» № 2168-VIII. [Law of Ukraine"On State Financial Guarantees of Public Health Services" October 19, 2017 № 2168-VIII]. http:// search. ligazakon.ua/l_doc2.nsf/link1/T172168.html (in Ukrainian).

6. Pakety medychnykh posluh. Zmist ta pidkhid do kontraktuvannya zakladiv okhorony zdorov"ya. [Medical service guidelines. Content and approach to contracting health care facilities]. National Health Care Service of Ukraine. Kyiv. 2020; 59. (in Ukrainian).

7. Soldatov I.B., Hoffman V.R. Otolarynholohyya. [Otolaryngology]. St. Petersburg. 2001; 472. (in Russian). 
8. Probst R., Grevers G., Iro G. Otorynolarynholohyya v klynycheskoy praktyke. [0torhinolaryngology in clinical practice]. Moscow. Practical Medicine. 2012; 243. (in Russian).

9. Slabky G.0., Prokopiv M.M. Epidemiolohiya tserebrovaskulyarnykh khvorob sered zhyteliv mista Kyyeva. [Epidemiology of cerebrovascular diseases among Kyiv residents]. Bulletin of social hygiene and health care organization of Ukraine. 2019; 4(82): 10-15. (in Ukrainian).

10. Krapivina A.A. Zakhvoryuvanist' na osnovni klasy khvorob ta poshyrenist' sered dorosloho naselennya Ukrayiny v hendernomu aspekti (2008-2010 rr). [Incidence of the main classes of diseases and prevalence among the adult population of Ukraine in the gender aspect (2008-2010)]. Ukraine. The health of the nation. 2012; 1 (21):51-55. (in Ukrainian).

\section{ORCID and contributionship:}

Vladyslav A. Smiianov: 0000-0002-4240-5968 ${ }^{E, F}$

Tetiana V. Yemets: 0000-0002-8449-6247 A, B, C

Yevhen V. Smiianov: 0000-0003-4996-1550 D, E

Polina O. Hornostaieva: ${ }^{B, D}$

\section{Conflict of interest:}

The Authors declare no conflict of interest.

\section{CORRESPONDING AUTHOR}

\section{Tetiana V. Yemets}

Sumy State University

2 Rimsky-Korsakov Street, 40000 Sumy, Ukraine

tel: +380661844909

e-mail: tanja-s2008@ukr.net

Received: 10.12 .2020

Accepted: 31.03 .2021

A - Work concept and design, B - Data collection and analysis, C - Responsibility for statistical analysis,

$\mathbf{D}$-Writing the article, $\mathbf{E}$-Critical review, $\mathbf{F}$ - Final approval of the article 